\title{
National Ideologies in the Era of Global Fusions: Georgian Polyphonic Song as a UNESCO-Sanctioned Masterpiece of Intangible Heritage
}

\author{
NINO TSITSISHVILI
}

\section{Introduction}

In the opening years of the twenty-first century, as part of its effort to sustain cultural diversity and human creativity in the face of the perceived effects of globalization, the United Nations Educational, Scientific and Cultural Organization (UNESCO) issued a series of proclamations and conventions that took steps to address the issue of the protection of the world's intangible cultural heritage. ${ }^{1}$ In its proclamation of 2001, UNESCO endorsed nineteen "masterpieces of oral and intangible heritage," including, on the recommendation of Georgian ethnomusicologists and folk-song experts, Georgian polyphonic singing. This event came to be perceived as an apotheosis of the Georgian musicological-folkloristic community's aspiration for Georgian polyphony to become an internationally acknowledged phenomenon to be protected from Russification, globalization, and the spread of Western popular music. Inclusion in the proclamation gave implicit international and legal endorsement to the official Georgian view of polyphony as a highly sophisticated musical form uniquely expressive of Georgian identity.

The song that served as exemplary justification for the recognition of Georgian polyphony was chak'rulo, a drinking song from the rural eastern province of K'akheti. More generally, however, the protected heritage also included secular and sacred polyphonic styles from other parts of Georgia, particularly sophisticated polyphonic songs and Christian chants from the western province of Guria. The eastern Georgian style, as exemplified in chak'rulo, consists of a three-part texture of two alternating solo male singers against a drone sung by a male chorus. The solo singers weave complex vocal lines full of ornamentation, a technique which is hard to accomplish without considerable practice and vocal talent. The western Georgian polyphonic style can be described as a contrastive-linear non-imitative polyphony comprising three independently developing vocal lines which produce an array of consonant and dissonant chords. Both eastern and western styles contain characteristic cadential formulae and tonal modulations in a modal scale system, which shift a song from one tonal center to another; this feature distinguishes the Georgian tradition from many other comparable traditions of the world, including those of Corsican or Albanian men's polyphonic singing.

\footnotetext{
${ }^{1}$ UNESCO, First Proclamation of Masterpieces of the Oral and Intangible Heritage of Humanity (2001); UNESCO, Second Proclamation of Masterpieces of the Oral and Intangible Heritage of Humanity (2003); UNESCO, Third Proclamation of Masterpieces of the Oral and Intangible Heritage of Humanity (2005); UNESCO Convention for the Safeguarding of the Intangible Heritage (Paris, October 17, 2003); UNESCO. Convention on the Protection and Promotion of the Diversity of Cultural Expressions, adopted by the General Conference of UNESCO at its 33rd Session (2005). These and other documents can be found on UNESCO official website: http://portal.unesco.org/
} 


\section{Audio Example 1: Chak'rulo [non-translatable]}

Accessible at: http://dx.doi.org/10.3998/mp.9460447.0003.104

Recorded in 1952 and released in $2006 .^{2}$

Description: An east Georgian traditional (folk) song. Chak'rulo presents one of the most sophisticated drone polyphonic styles practiced in the villages of $\mathrm{K}$ 'akheti province; its highly ornamented style requires outstanding vocal skills, as a result of which not so many ensembles either in Georgia or outside of Georgia are able to include it in their repertoires.

\section{Audio Example 2: Khasanbegura}

Accessible at: http://dx.doi.org/10.3998/mp.9460447.0003.104

Recorded by the author at one of the concerts of The 3rd International Symposium for Traditional Polyphony, 25-29 September 2006, Tbilisi.

Performed by the ensemble "Basiani."

Description: This is a song about the leader of Ach'ara, an Islamized province of west Georgia that was under Ottoman rule until the Russians took over in the nineteenth century.

The UNESCO proclamation was followed by and ceremonially marked with the First International Symposium on Traditional Polyphony, held in Tbilisi, on 2 October 2002, under the patronage of Georgian president Eduard Shevardnadze. The proclamation also facilitated the establishment of the International Research Center for Traditional Polyphony (IRCTP) within the Department of Georgian Musical Folklore at the Tbilisi State Conservatorium in 2003. ${ }^{3}$ The opening ceremony of the Symposium was held in the big concert hall of the Tbilisi State Conservatorium. The senior staff of the Tbilisi State Conservatorium, participating foreign scholars (including myself as a Georgian expatriate from Australia), and the organizing committee of the Symposium and future IRCTP sat on the stage, while other guests including Conservatorium students, local scholars and folk singers and ensembles were seated in the hall. From my place on the stage, I heard speeches in praise of Georgian culture and polyphonic song given by such prominent figures as Anzor Erkomaishvili, the director of the International Center of Georgian Folk Song and forefather of folk-song preservation and revival projects in Georgia, as well as President Shevardnadze. Witnessing this unique historical moment, I felt I was caught in the crossroad between music/ology and politics.

After the ceremony, in a private conversation with a liberally-minded colleague (many others were in the euphoria of a patriotic pride elicited by the UNESCO proclamation), the question arose as to whether Georgian polyphony was in real need of protection from UNESCO. Such a question seemed relevant considering the fact that Georgian polyphonic songs have become an internationally known world music phenomenon, and have been implicated in almost all the hybrid music styles and musical experimentations in Georgia that have emerged in classical, modern art, and popular music since the end of the nineteenth century. Georgian polyphony had also been performed by many professional and community choirs around the world prior to UNESCO's proclamation. ${ }^{4}$

\footnotetext{
${ }^{2}$ K'akheti 1952. The Tbilisi State Conservatoire Field Expedition Recordings. CD published by International Research Center for Traditional Polyphony at Tbilisi State Conservatoire. 2006.

${ }^{3}$ Since 2007, following a reorganization of the education system and institutions, the Department of Georgian Musical Folklore/Ethnomusicology became integrated as a separate entity within the larger Department of Music Theory, with its own Director, teaching and assisting staff.

${ }^{4}$ A sampling of the global discography of Georgian polyphonic songs includes Darbazi \& Friends. Music from Beyond the Black Sea (CD, Toronto: Deep Down Productions, 2001); Golden Fleece: Songs from Georgia (CD MCD 127, Move Records [Australia],
} 
This article attempts to analyze the case of Georgian polyphony in relation to UNESCO's concept of "intangible cultural heritage" and associated discourses about rights to culture. ${ }^{5}$ The article also aims to situate the discussion of these discourses in relation to global processes and their impact on local Georgian cultural-artistic expressions and the politics of culture. While certain concepts advocated by UNESCO in relation to cultural diversity and heritage are transformed and resisted by local national ideologies and cultural policies according to local practices within Georgia and other societies, other aspects of UNESCO's philosophy in fact coincide with the traditionalist and mono-ethnic nationalist dispositions of the Georgian ethnomusicological elite and culture policy makers.

The article argues, thus, that long-term nationalist cultural policies endorsing the primacy of Georgian traditional polyphony have found a new ideological niche within the discourse of "rights to culture." The examination of Georgian polyphony in close association with the rights to culture discourse is also necessary because such examination reveals the ways in which universal categories of the rights of a group or individual to cultural expression are implemented, defied, and altered in local contexts. For example, the article examines contradictions between the multi-cultural and multi-ethnic character of Georgia's population on the one hand, and the proclamation by UNESCO of only one form of artistic expression to be uniquely representative of Georgian identity and the Georgian nation on the other. It also points to the inconsistency in UNESCO's conception of culture as uniquely ethno-specific, and asks why only traditional ethnic forms of music can qualify as "intangible heritage" while local adaptations of modern Western popular music such as rock, pop, and rap cannot.

A philosophy based on concepts of "heritage" and "culture" inadvertently divides music into the communal "folk music" genres rooted deeply in the people's social practices and historical past on the one hand and, on the other, the modernized, recently transplanted and rapidly changing mass culture of popular music genres, including rock, hip-hop and the experimental electronic and folk-fusion styles brought about by globalization. Therefore, while the article takes Georgian polyphony and the proclamation which recognizes it as a "masterpiece of the oral and intangible heritage of humanity" as starting points for the examination of culture, it also involves a broader spectrum of issues in current ethnomusicology such as those of subject matter and methods. In particular, I will discuss Georgian polyphonic song and the UNESCO concept of cultural heritage in relation to discourses of tradition, authenticity and folklore as tested, often too straightforwardly, against innovation, commercialization, and the modernization of previously deep-seated cultural practices of the whole community, or the "whole way of life" of which "folk music" is seen to be a part.

\footnotetext{
1999); Kavkasia. Songs of the Caucasus Sung by Trio Kavkasia (CD WTP 5178, Well Tempered World Productions [U.S.A.], 1995); O Morning Breeze: Traditional Songs from Georgia Sung by Trio Kavkasia (CD 76014-2, Naxos World label [Canada], 2001); Carl Linich, Drinking Horns \& Gramophones. The First Recordings in the Georgian Republic, 1902-1914 (CD 4307-2, New York: Traditional Crossroads, 2001); Soupra Marani, Le banquet Géorgien (CD, Paris: ARB Music, 1998); Mravalzhamier. Traditional Georgian Songs Recorded Live in Australia and New Zealand (CD BOITE 013, 2004).

${ }^{5}$ The discourse of rights to culture, or the notion according to which each nation or a group of people has rights to culturally distinctive forms of expression, emerged as a response to the earlier conception of antagonism between culture and rights. This antagonism was conceived of as an inherent tension between the cultural relativism and awareness of cultural differences as espoused by nineteenth century German Romanticism and the universalism of human rights across cultures as espoused by the French Enlightenment. In more recent scholarship there is a tendency to find a middle ground between human rights and cultural differences and to think of culture not as a set of fixed meanings but as a field of creative interchange, negotiation, contestation, and transformation. See Jane K. Cowan, Marie-Bénédicte Dembour and Richard A. Wilson, "Introduction," in Culture and Rights: Anthropological Perspectives, ed. Jane K. Cowan, Marie-Bénédicte Dembour, and Richard A. Wilson (New York: Cambridge University Press, 2001), 4-5.
} 


\section{Georgian polyphony and the paradoxes of culture}

Today's international discourse of rights is "hegemonic, and imbued with an emancipatory aura. Yet this model has had complex and contradictory implications for individuals and groups whose claims must be articulated within its terms." "In present-day Georgia, the right to culture discourse legitimates claims of ethnic Georgians to ethnic and cultural hegemony within a multi-national state and their notion of a single, mono-ethnic Georgian identity. It also articulates Georgians' fears of an internal fracturing of statehood, fears which were manifested and aggravated by the dissent and de-facto secession of the Autonomous Republic of Abkhazia and the Autonomous Region of South Ossetia (both formerly provinces of Georgia). The discourse of right to culture helps Georgians and especially the cultural elite ${ }^{7}$ to situate themselves as righteous defenders in need of protection from threats of state disintegration, cultural homogenization, the rural exodus and the consequences of former Soviet policies.

Concerns about globalization evident in UNESCO ideology invoke certain paradoxes. Firstly, we might argue that UNESCO is itself a product of globalization and increased collaboration between the different states and organizations of the world. Secondly, globalization has actually helped Georgian polyphony and many other designated "masterpieces of intangible heritage" to become known internationally and has facilitated processes of exchange and collaborative experimentation among practitioners of various cultures. ${ }^{8}$ Scholars have increasingly argued against the overtly negative perception of the effects of globalization and have instead proposed that the global dissemination and Americanization of cultural products creates new differences, transnational collaborations and local meanings, and constitutes a process based on a constant mix between local and global-Western forms of culture and values. ${ }^{9}$ Also inherent in UNESCO's protective policy is the paradoxical tendency, identified in anthropological studies, according to which the right to culture discourse often invents and adjusts historical reality in order to justify its demands for the preservation of certain forms of cultural expression. For example, the text of the 2001 UNESCO proclamation ${ }^{10}$ clearly exaggerates the devastating effects of Soviet cultural policies on Georgian polyphony. It is true that these policies entailed many artificial changes in the area of folk music, including the enlargement of choirs to express the Soviet dogma of mass proletarian involvement and the expansion of repertoire to include newly arranged and composed folk songs which, in the opinion of its critics, distorted the nature of folklore. Nonetheless, Georgian polyphonic choral singing as a national identity marker received more funding and institutional support in Soviet times than it does now. ${ }^{11}$ In fact, the rights to culture discourse is not so distinct in principle from the Soviet policy of samoop'redelenije naroda (selforientation of an ethnicity), which affirmed the right of every ethnicity within the Soviet Union to preserve its distinct culture, despite distortions in practice by Soviet authorities.

The concept of UNESCO's “intangible heritage" and its interaction with Georgian cultural policies provides an interesting context within which one may analyze and reveal some of the complexities and

\footnotetext{
${ }^{6}$ Cowan, Dembour and Wilson, 1.

${ }^{7}$ Since the nineteenth century Georgia's cultural elite-writer-politicians, poets and the intelligentsia (the Soviet-coined name for the creative elite) - has acted as the nation's spiritual fathers. Members of the elite study history, ancestral heritage, and folklore and envision the nation's future as an independent and culturally unique country and a member of the civilized world.

${ }^{8}$ Hans Van Ginkel, "Cultural Heritage, Identity Formation and Change in a Globalizing World, "in Globalization and Intangible Cultural Heritage, International Conference, Tokyo, Japan, August 26-27, 2004, UNESCO, 25 (http://unesdoc.unesco.org/images/0014/001400/140090e.pdf).

9 Koichi Iwabuchi, "Transnational Media Culture and the Possibility of Transgressive Dialogues," in Globalization and Intangible Cultural Heritage, UNESCO, 130-1. (http://unesdoc.unesco.org/images/0014/001400/140090e.pdf). For the local adaptations of American rap to Japanese language see Noriko Manabe, "Globalization and Japanese Creativity: Adaptations of Japanese Language to Rap," Ethnomusicology 50, no. 1 (2006): 1-36.

${ }^{10}$ See note 1 above.

${ }^{11}$ Georgian ethnic nationalism flourished more than ever during the Soviet era. See Ronald Grigor Suny, The Making of the Georgian Nation, 2nd ed. (Bloomington and Indianapolis: Indiana University Press, 1994), 290.
} 
paradoxes of liberal democracy building, and show the ways in which post-socialist countries combine ideals of liberal democracy with tradition- and culture-oriented practices. The prominent Georgian political philosopher Ghia Nodia has argued that the building of Western-style liberal democracy is not incompatible with nationalism, but that these are two sides of the one idea and the two major principles of political discourse generally. ${ }^{12}$ A related proposition is that only politically, militarily and economically secure states can be pluralistic, while weaker states, in the absence of security, are much more likely to adopt, maintain, or revert to centralized structures. ${ }^{13}$ It seems that, because of Georgia's fractured and fragile statehood and economy, a striving for Western values and democracy in that country has been combined with heightened and persistent expressions of cultural nationalism. In such a fragile political situation, those who try to preserve "intangible heritage" pit the concepts of "national identity," "tradition" and "culture" against the assumed threats of non-native influences and the cultural hybridity of the Georgian state.

In the twenty-first century, UNESCO has elaborated on its notions of culture in declarations and reviews of its vital strategies. The Declaration of 2001 affirms that culture "should be regarded as the set of distinctive spiritual, material, intellectual and emotional features of society or a social group, and that it encompasses, in addition to art and literature, lifestyles, ways of living together, value systems, traditions and beliefs." ${ }^{14}$ In the Convention of 2005, culture is seen as a source of identity, of development, and of dialogue and exchange of ideas between different societies, and each social group and individual is entitled to access to their cultural expressions. ${ }^{15}$ Central to the critique of UNESCO's concept of culture has been the question of compatibility between cultural relativism and universal humanism (human rights), between the rights of cultures collectively and the rights of individuals within those cultures, between local cultural expressions and universal ethics. Critics have questioned UNESCO's ability to address the institutional and hierarchical power relationships and identity politics inherent in claims by each state and nation to collective cultural rights. As Eriksen's and other critiques have pointed out, the UNESCO concept of culture presents an idealistic view of the world as made up of diverse cultures which are supposed to live in harmony and mutual respect based on global ethics and human rights. ${ }^{16}$ However, it is not clear how UNESCO intends to implement cultural diversity and mutual tolerance according to the rules and procedures formulated in its conventions; what is its strategy to organize the world politically so that all its diverse artistic expressions and ethnic-cultural identities embrace each other and exchange ideas? Such exchanges of artistic ideas seem to occur without institutional and political interventions such as UNESCO's. This uncertainty emanates from an ambivalent and uneasy positioning of UNESCO's philosophy of sustainable cultural development at a crossroads of politics and culture, between an ideology of creativity and diversity of artistic expression and one of cultural policies and identity politics. Ambiguity also derives from the fact that the notion of culture has become too over-burdened with various meanings, and has merged with many other discourses such as

\footnotetext{
${ }^{12}$ Ghia Nodia, "Rethinking Nationalism and Democracy in the Light of Post-Communist Experience," in National Identity as an Issue of Knowledge and Morality, Georgian Philosophical Studies, I, ed. N.V. Ch'avch'avadze, Ghia Nodia and Paul Peachey (1994) (http://www.crvp.org/book/Series04/IVA-7/contents.htm); Ghia Nodia, "Georgia's Identity Crisis," Journal of Democracy 6, no. 1 (1995): 105.

${ }^{13}$ Mark E. Pietrzyk, International Order and Individual Liberty: Effects of War and Peace on the Development of Governments (Lanham, MD: University Press of America, 2002). While nationalism and liberal democracy are compatible as political systems, at a philosophical-ideological level there still arises a contradiction between being liberal and being nationalist, especially in countries like Georgia, which tries to silence cultural diversity in order to avoid ensuing territorial claims by different cultural-ethnic communities.

${ }^{14}$ UNESCO Universal Declaration on Cultural Diversity (2001/2002). This source can be viewed at http://unesdoc.unesco.org/images/0012/001271/127160m.pdf

${ }^{15}$ UNESCO. Convention on the Protection and Promotion of the Diversity of Cultural Expressions, adopted by the General Conference of UNESCO at its 33rd Session, 2005, 10-11. This source can be viewed at: http://unesdoc.unesco.org/images/0014/001429/142919e.pdf

${ }^{16}$ Thomas Hylland Eriksen, "Between Universalism and Relativism: A Critique of the UNESCO Concept of Culture," in Cowan, Dembour and Wilson, 129.
} 
those on human rights, law, indigenous law, cultural policies, minority rights etc. ${ }^{17}$ For decades, anthropologists and ethnomusicologists have been trying to redefine, develop and even discard the concept and term culture in an attempt to accommodate in their analyses those multiple intersecting fields of human society, politics, and artistic expression.

UNESCO has shown a considerable self-reflexivity and given some thought to its conceptual framework in order to reconcile and combine universal human values with its specific cultural development strategies. In earlier stages of its existence, UNESCO worked towards tolerance and peace between nations and societies, whereas more recently it has also begun to focus on the links between culture, democracy, and tolerance between the different segments of one nation, including minorities. As an internal study of 2004 states: "Evidence of tensions on a variety of levels (local and regional, as well as international) has led to a focus on intra-societal problems, especially in urban centers, and on the theoretical and practical questions of minority rights and the coexistence of diverse cultural communities." 18 There have been some terminological changes, such as replacing "preservation" with "safeguarding" on the premise that "preservation" carries paternalistic connotations, and replacing "traditional culture" and "folklore" with culture as a site of contestation rather than as an outcome of a homogenous agreement between all members of a community. ${ }^{19}$ Nevertheless, such substitute terms are not always capable of carrying essentially new meanings; In fact, there is still a strong sense of culture as associated with "tradition" and "folklore" and with geographically and ethnically specific groups, as opposed to non-specific forms of artistic expression which are seen as too Westernized, globally homogenized and otherwise corrupt and detached from social practice and a "whole way of life." "Heritage," as interpreted in the organization's presentation videos and in the ethnomusicological-anthropological vocabulary utilized in its conventions and publications, suggests UNESCO's enduring subscription to this ethnicity- and locality-based notion of culture. Since proclamations of intangible heritage involve predominantly non-Western, Oriental, and European folk traditions, UNESCO inadvertently focuses either on "traditional" societies (which, according to persistent colonial and Orientalist thinking, are supposed to have "folk" culture), or on the enduring concepts of ethnicity and tradition ${ }^{20}$ within developed European societies.

\section{Cultural heritage and nation-building}

At its general conference in 2003, UNESCO adopted The Convention for the Safeguarding of the Intangible Cultural Heritage. ${ }^{21}$ This convention acknowledges that there are challenges and complexities involved in implementing programs that seek at once to promote cultural diversity and a respect for human creativity and to protect intangible heritage, since each country has its own specific characteristics which vary from region to region depending on the level of endangerment. As has been argued by its critics, however, the UNESCO concept of culture fails to engage in a serious debate around the question of how

\footnotetext{
${ }^{17}$ See Cowan, Dembour and Wilson, 14 (and the rest of the article).

${ }^{18}$ UNESCO and the Issue of Cultural Diversity, Review and Strategy, 1946-2004. A study based on official documents (UNESCO: Division of Cultural Policies and Intercultural Dialogue, revised version, September 2004), 4. See also UNESCO. Convention on the Protection and Promotion of the Diversity of Cultural Expressions (2005).

${ }^{19}$ See Wim Van Zanten, "Constructing New Terminology for Intangible Cultural Heritage," Museum International 221-222 (56, no. 1-2, 2004): 37.

${ }^{20}$ This way of thinking resembles the colonial view of developing countries more as "cultures" and "ethnicities," while developed, dominant countries are viewed as sites for "politics." For example, "ethnic conflict" occurs between Georgians and Abkhazians or between Serbs and Kosova Albanians, but the "war on terror" or the political struggle for the establishment of democracy happens between the U.S.A. and the Muslim world. The Georgian political scientist Ghia Nodia has criticized the application of "ethnic conflict" to the Abkhazian-Georgian war and argued instead that this is a territorial-political conflict in his Causes and Vision of Conflict in Abkhazia (Berkeley: University of California, Berkeley Program in Soviet and Post-Soviet Studies, 1997-8), 3-4.

${ }^{21}$ UNESCO Convention for the Safeguarding of the Intangible Heritage (2003).
} 
local political processes and identity politics will affect the realization of the UNESCO ideology. ${ }^{22}$ The fact that UNESCO conventions are ratified by parliaments and governments raises the concern that attempts to safeguard the cultural expressions of diverse community groups within a country will be implemented in accordance with the state's hegemonic cultural policies and transformed by local concerns and politics that might exclude culturally diverse groups and preclude dialogue between them. Such a possibility specifically exists in countries like Georgia, Russia, or Serbia which have been fractured by internal and external territorial-political conflicts and disputes. UNESCO's commitment to fostering a model of cultural diversity thus does not seem to be very fruitful, for its proclamations paradoxically tend towards an apparent endorsement of a monoethnic nationalist vision. In Georgia's case, the 2001 proclamation served to sanction existing monoethnic identity politics that have defined Georgia's progress towards nationhood and political independence for the last two centuries. In these local political circumstances, "intangible heritage" is understood as the national, ethnically Georgian heritage.

As in much of the eastern European world, the emergence within Georgia of ideas similar to those advocating the protection of intangible heritage and those expressing concerns about cultural identity occurred in the late nineteenth century, at the time of the national-liberation movement within the Russian Empire; it was then that polyphonic song became privileged by the educated elites over other forms of musical expression of Georgianness. Polyphonic singing is still viewed by Georgian ethnomusicologists and the nationalist elite as the principal form of communal music-making of the autochthonous ethnic rural farming communities of the Caucasus Mountains and the valleys of eastern and western Georgia. The sophistication of some regional polyphonic styles underpins the cultural establishment's view that Georgian polyphony expresses the creative genius of the Georgian people and elevates the status of Georgian culture within European civilization.

However, despite its hegemony, polyphony is not the only form of music practiced within the country that can be seen as defining group identity. So far the activities of the IRCTP have been limited to the documentation of what its members consider the purest ancestral heritage of Georgian polyphony and the related tradition of polyphonic Christian chanting. On the other hand, research into other areas of musicsuch as, for example, the Armenian and "Middle Eastern"-related duduki (a double-reed aerophone with a cylindrical bore, widely used in the Middle East and Transcaucasia), the zurna (a double-reed aerophone with a conical bore also widely used in the Middle East and Transcaucasia), and the Azerbaijani-Persian classical art music genre of mugham that has infiltrated parts of eastern and southern Georgia—is explicitly and implicitly discouraged.

Audio Example 3: Baiati Shuri [Bayat (a Georgian term for mugham/mak'am) Shuri] Accessible at: http://dx.doi.org/10.3998/mp.9460447.0003.104

Recorded by the author in the village of Vardisubani, in the Dmanisi district of south-eastern Georgia), September 2006.

Performed by Dmanisi duduki player Emina Minashvili (solo), and his fellow musicians Longinoz (drum) and Durmishkhan (bass duduki).

Description: Georgian traditional music for $d u d u k i$ and drums related to the style of Middle Eastern makam.

${ }^{22}$ Susan Wright, “The Politicization of 'Culture'," Anthropology Today 14, no. 1 (1998): 7-15; Eriksen. 
In 2007, my suggestion to the staff of a center dedicated to the research and collection of folklore in Georgia that it record Armenian $d u d u k$ players from south Georgia was met with the response that the institution's equipment was meant to be used for documenting elderly village singers of polyphonic songs. Polyphony was and still is privileged because of its association with ethnic rural Georgians, while the $d u d u k i$, mugham, and other hybrid musical styles influenced by non-native or popular music prevailed in urban cosmopolitan centers, areas where Armenians, Azeri, and other non-Georgians lived and continue to live, albeit now in smaller numbers.

The privileging of polyphony in Georgia thus clearly points to the politicized and problematic nature of cultural identity, which is addressed by the UNESCO programs and conventions but is difficult to implement strategically in each state. The question arises as to whether it is possible to draw a clear line between cultural identity and diversity as promoted by the UNESCO programs and the politicized repackaging of cultural identity as carried out by Georgia and other states and groups claiming cultural rights. In the Georgian context, UNESCO functionaries such as "agents," "bearers," "custodians," "managers," and "administrators," who are supposed to implement the conventions and represent communities, happen to be patriots who, though they genuinely care about Georgian polyphony, also genuinely do not care about (and are even afraid of) non-native musical expressions.

The politicized role of culture in Georgia's political development is clearly shown in the March 2007 issue of Georgia Today, ${ }^{23}$ in a letter about the upcoming Georgian Season 2007, a cultural project initiated and funded by the Presidential National Program. Quoting the State Minister for the European and EuroAtlantic Integration of Georgia, the letter asks rhetorically: "Is Georgia a part of Europe or not? After the Georgian Season makes its way through Europe this won't even be a question. We are Georgians and we are Europeans - this must be clear for both our friends and our enemies." Among other non-musical artworks, Georgian culture was to be represented by polyphonic songs, and reference was made to the UNESCO Proclamation of 2001. It seems, then, that within the specific political context of Georgia, the idea of Georgian polyphony as a masterpiece of intangible heritage implicates issues and identity politics that are more complex than the romanticized (although constantly negotiated and redefined) ethics and strategies of cultural diversity and human creativity advocated by UNESCO. Polyphony carries a specific diplomatic burden, nationally and internationally.

If UNESCO's idea is to promote cultural diversity and dialogue between cultures, what does it signify that the Proclamation acknowledges only one form of artistic expression to be uniquely representative of Georgian identity and the Georgian nation? Georgia is a multi-ethnic and multi-cultural country. There are regions, especially in eastern and southern Georgia, where polyphony is either not practiced, or at least does not represent the core of the people's identity and social practice. Many duduki players would argue that duduki music expresses another localized, but still uniquely Georgian, communal spirit and that it, too, needs protection. The music of the $d u d u k$ is in fact protected by the UNESCO Proclamation from 2005, but as an Armenian art form expressing Armenian identity within Armenia; protection does not extend to the distinctive tradition of duduki in Georgia, where duduki music is endangered by official policies of exclusion as well as by globalization, ${ }^{24}$ or to the tradition of the Azerbaijani balaban, the equivalent of Armenian and

\footnotetext{
${ }^{23}$ Georgia Today, no. 347 (March 2007), available from http://www.georgiatoday.ge/index.php, accessed 31 May 2007. While Georgia Today includes back issues on its website, issues earlier than no. 350 are no longer available.

${ }^{24}$ For a fuller discussion of these issues, see Nino Tsitsishvili, "Social and Political Constructions of Nation-Making in Relation to the Musical Styles and Discourses of Georgian Duduki Ensembles," Journal of Musicological Research 26, no. 2-3 (2007): 241-80.
} 
Georgian $d u d u k$ and $d u d u k i .^{25}$ Therefore, duduki players and scholars studying duduki music on Georgian territory do not have access to the same benefits of UNESCO recognition as do those based in Armenia.

The exclusive UNESCO emphasis on one Georgian musical soundscape corresponds to the state's attempts to assimilate ethnic minorities as a means of resolving critical situations that have formed around the Armenian and Azeri Diasporas, and of preventing further loss of territories following the secession of Abkhazia and the South Ossetia. In this climate of inter-ethnic tension, any official recognition of the cultures of minorities and Diaspora groups could also give implicit sanction to their demands for political autonomy, threatening the state's territorial integrity by potentially reinforcing the secessionist tendencies which accentuate the vulnerability of Georgia's "fissile" statehood. ${ }^{26}$

\section{The problem of intra-national dialogue in an international cultural body}

Despite the shifts in philosophical position mentioned above, UNESCO policy seems more readily to promote dialogue and cultural diversity between different states rather than between different communities within one state. As mentioned in the 2004 UNESCO review of the issue of cultural diversity, initially, "the idea that UNESCO would reach over the heads of governments and engage people directly was contrary to its mandate and would likely have prevented the formation of the Organization as a whole."27 Even though member states have been encouraged to promote cultural diversity both within and outside their borders since the $1990 \mathrm{~s},{ }^{28}$ the local implementation of this goal is often affected by national identity politics. Accordingly, while the IRCTP organizes bi-annual International Symposia which host scholars and choirs from different countries and publishes its bulletin in Georgian and English, it does not promote dialogue between the different ethnic and cultural communities within Georgia, nor scholarship concerned with these communities.

This latter critique could be contested on the grounds that UNESCO proclamations do protect the cultures of the indigenous populations of the Americas. However, two doubts can be expressed in this connection. Firstly, we deal again with the Orientalist conception that indigenous "tribal" people need protection. Secondly, we have to remember that the term "indigenous" carries completely different implications and meanings in the case of Georgians than it does in the case of the Australian or American aboriginal populations. In Georgia, the indigenous population is the nationality that has been dominant throughout its long history, despite threats posed by weak statehood and powerful neighboring countries. In Australia and the Americas, the indigenous population is that which was in the land when the Europeans arrived; such populations are definitely not dominant, nor are they powerful in any political sense. Proclaiming an American indigenous cultural practice as an intangible heritage worthy of preservation and protection might be read as implying a measure of compensation for the usurpation of political power from this population, but it does not necessarily give the people political rights or endorse any secessionist tendencies. The Georgian reality is different. Ethnic or religious minorities in Georgia, such as the Armenians and Azeris, maintain strong political connections with their "mother countries," and their claims to cultural autonomy are, indeed, often implicitly or explicitly linked to political-territorial disputes and historical rivalries.

\footnotetext{
${ }^{25}$ On the question of political and cultural contest between the Armenian $d u d u k$ and the Azerbaijani balaban within the context of UNESCO's intangible heritage, see Natasha Kipp (forthcoming), "Creating a Cultural Battlefield: Musical 'Masterpieces' and the Role of UNESCO," in Cultural Archetypes and Political Change in the Caucasus, ed. Nino Tsitsishvili and Sergey Arutiunov (New York: Nova Science Inc.).

${ }^{26}$ The concept of the "fissile state" is borrowed from Paul Jackson, "Ethnicity, Decentralization and the Fissile State in Georgia," Public Administration and Development 24 (2004): 75-86. It refers to the tendency within states towards provincially- and ethnically-based secession and territorial fragmentation.

${ }^{27}$ UNESCO and the Issue of Cultural Diversity, Review and Strategy, 1946-2000 (UNESCO: Division of Cultural Policies, 2000$), 6$.

${ }^{28}$ UNESCO and the Issue of Cultural Diversity, Review and Strategy, 1946-2000 (2000), 4, 22.
} 
Who, then, might be imagined to engage in UNESCO's goal of cultural dialogue within and without the Georgian state? Is it to take place between Georgians and their Armenian and Azeri minorities; between ethnomusicologists from Georgia (and other countries) who also work on polyphony; or between Georgian choirs and the choirs from Western countries who sing Georgian polyphony? One thing is clear: UNESCO and its ideal vision of a tolerant multi-cultural world would not be allowed to interfere with Georgia's integrity or internal political affairs in relation to its ethnic minorities.

As an ethnically and culturally heterogeneous country, Georgia could, alternatively, choose to embrace a concept of plural identity such as is promoted by the UNESCO Universal Declaration of Cultural Diversity in 2001, that would see polyphony recognized alongside the duduki, the zurna, and mugham. This is not, however, the present reality. Three factors contribute to this: firstly, the concept of cultural plurality promoted by UNESCO is hard to translate into Georgian society, which has experienced decades of a totalitarian regime and the subsequent lack of freedom of speech and of thought, and has no history of teaching political science, social anthropology, or cultural studies. Secondly, an ambiguity is inherent in UNESCO's policy itself: it promotes cultural diversity and cultural inclusiveness, but also implicitly supports cultural exclusiveness and monoethnicity by recognizing only one musical form, in this case polyphony. Thus, conferences and research in Georgian ethnomusicology are organized around this one specific structural component of music, rather than promoting dialogue between researchers of various musical cultures. This unitary concentration certainly brings together scholars who work on polyphony from different cultures, but the non-polyphonic and non-native musics of Georgia are not admitted to the dialogue. Thirdly, and most importantly, the state's fissile character generates an insecurity that inhibits the implementation of this idealized notion of cultural inclusiveness.

\section{The role of popular music and the fear of globalization in UNESCO policy}

Those experts who recommended Georgian polyphony for proclamation as a masterpiece of intangible heritage have also expressed concern over the consequences of industrialization, the rural exodus, and the increasing popularity of contemporary pop music, ${ }^{29}$ a concern often shared by Western experts and UNESCO. UNESCO understands that globalization, while having economic benefits, can be dangerous to ethnic cultures. ${ }^{30}$ It seems that innovation, as it is understood within UNESCO programs and operations, is a concept which attaches only to developments within existing folk music styles, forms, and performers. Experimental fusions involving folk styles are not seen as innovation of the existing heritage, perhaps because their practitioners might not see themselves as continuing an "intangible heritage," and the same exclusion applies to modern genres which have been transmitted from generation to generation within relatively short time periods. The concepts of "innovation" and the "new" figure in some of the UNESCO documents and publications related to the concept of cultural heritage and cultural change. ${ }^{31}$ In most cases, however, these terms are used in very general terms as part of the vexing concept of "continuity and change," without a thorough explanation of what sort of specific forms are open to cultural "innovation." The UNESCO Convention on the Protection and Promotion of the Diversity of Cultural Expressions (2005)

\footnotetext{
${ }^{29}$ See Anzor Erkomaishvili, "Martve" 20 Ts'lisaa ["Martve" Is Twenty Years Old] (Tbilisi: Ts'igni, 1997), 61; BBC NEWS, "Choirs of the World: Georgian Polyphonic Songs," available from http://news.bbc.co.uk/2/hi/entertainment/3332111.stm, 2003/12/24, accessed 20 March 2008.

${ }^{30}$ Koichiro Matsuura, "Globalization, Intangible Cultural Heritage and the Role of UNESCO," in Globalization and Intangible Cultural Heritage, UNESCO (http://unesdoc.unesco.org/images/0014/001400/140090e.pdf), 17; Peter J. M. Nas, "Masterpieces of Oral and Intangible Culture: Reflections on the UNESCO World Heritage List," Current Anthropology 43, no. 1 (2002): 142.

${ }^{31}$ UNESCO Universal Declaration of Cultural Diversity (2001), 11, 13; Mervyn Claxton, Culture and Development: a Study (1994), http://unesdoc.unesco.org/images/0009/000970/097070e.pdf, 55; Antonio A. Arantes, "Global Opportunities for Intangible Heritage," Globalization and Intangible Cultural Heritage, 69.
} 
states that "As a continuing, flexible and changing process, culture remodels tangible and intangible cultural heritage, while inventing new forms of expression" and sees invention, innovation, and imagination as fostering mutual understanding and dialogue between cultures. ${ }^{32}$ In other related documents, however, "innovation" is seen, ambiguously, both as a positive effect of globalization and as causing the marginalization of certain vulnerable cultures. ${ }^{33}$ Within such general and ambiguous definitions it is not clear whether hip-hop in Georgia can qualify as a "new" or "innovative" practice based on heritage. Emerging in the early 1990s as a new form of global pop, hip-hop became a leading mainstream genre. ${ }^{34}$ Like "folk song," hip-hop has been transmitted from an older generation of rappers to the relatively young generation of hip-hop bands that perform and record today. Nevertheless, hip-hop cannot qualify as "intangible heritage" and healthy innovation.

Clearly, UNESCO's political philosophy coincides with certain philosophies adopted in Georgian ethnomusicology concerning research priorities and the established methods and subject matter of inquiry. Taking into account the increased interest in the diverse forms of popular music among a younger generation of ethnomusicologists, UNESCO's position seems to be even more anachronistic, with its focus on "tradition" and "heritage." 35 UNESCO's definition of culture as an artistic creativity whereby humans express themselves collectively and individually, transcend the limitations of self and seek for new meanings, ${ }^{36}$ could easily be applied to any genre of music. Similarly, we may argue that the categorizations selected by $\mathrm{UNESCO}^{37}$ as characteristic of "intangible heritage" —oral traditions and expressions, performing arts, social practices, and knowledge and practices concerning nature and the universe-are also applicable to popular music genres. ${ }^{38}$

In the era of globalization, rapid changes and diversification in the production and consumption of popular music, the dynamic emergence of new sub-cultures and popular music's perceived effects of deterritorialization and universalization of music styles have pitted Georgian popular music against the continuity and rootedness of folk polyphony. The persistent reverence for the concepts of culture in the sense of folklore, continuity, and community has played a central role in UNESCO's proclamations as well as being one of the major reasons why local nationalistic cultural policies find a comfortable niche in UNESCO's concepts of cultural diversity and intangible heritage. Additionally, the politics of folk culture since the eighteenth century, when Johann Gottfried Herder ${ }^{39}$ proclaimed it as part of national spirit and ethnic identity, have assumed strongly nationalistic overtones, especially in countries such as Georgia, which has a history of liberation movements against the empires of Ottoman Turkey, Safavid Iran, and Russia. In this climate, folklore assumed the role of an ideological commodity. ${ }^{40}$

\footnotetext{
${ }^{32}$ UNESCO. Convention on the Protection and Promotion of the Diversity of Cultural Expressions (2005), 3, 12.

${ }^{33}$ UNESCO and the Issue of Cultural Diversity, Review and Strategy, 1946-2004 (Revised version 2004), 19.

${ }^{34}$ Paul Rimple, Georgian Hip Hop: Creating a Beat for the Caucasus (December 8, 2006), available from

http://www.eurasianet.org/departments/insight/articles/eav120806.shtml, accessed 30 March 2008.

${ }^{35}$ It is no surprise that anthropologists and ethnomusicologists, not popular music scholars, are more likely to serve as experts who give recommendations to UNESCO.

${ }^{36}$ UNESCO and the Issue of Cultural Diversity, Review and Strategy, 1946-2000 (2000), 14-15.

${ }^{37}$ UNESCO Convention for the Safeguarding of the Intangible Heritage, 3.

${ }^{38}$ On the discussion of the relevance of the folk music/popular music division see Richard Middleton, Studying Popular Music (Milton Keynes [England]; Philadelphia: Open University Press, 1990), 127-53.

39 Johann Gottfried Herder, Selected Early Works, 1764-1767, trans. Ernest A. Menze with Michael Palma (University Park: Pennsylvania State University Press, [1764-1767] 1992).

${ }^{40}$ Regina Bendix, "Final Reflections: 'The Politics of Folk Culture' in the 21st Century,” Etnográfica 9, no. 1 (2005):195.
} 


\section{Whose polyphony? Rural populations and urban elites}

Georgian ethnomusicologists' focus on folk polyphony as opposed to popular music links them with the specific "face-to-face collective" anthropological definition of "folk culture," which is supposedly inapplicable to popular music. Ideological overtones involved in the concepts of "tradition," "folklore," and "cultural heritage" are also related to modern Western and Westernized intellectuals' exotic longing for small "face-to-face communities," which are being eradicated by industrialization of the capitalist society and whose musics are threatened by the spread of Western-derived popular music genres. Yet such an intellectual position invites us to ask where this idealized notion of polyphonic culture actually exists today: in the rural communities as the experts of folk song insist, or in urban intellectual elite circles? In Georgia at least, polyphonic song is increasingly practiced by urban (and modernized rural) intellectuals and their folklore ensembles; more recently, it is also practiced globally by community choirs and professional singers, especially in the U.S.A., Canada, U.K., France, Australia and Japan. It is practiced less by its supposed bearers, the "folk" communities of Georgian villages. Many of these villagers, to the dissatisfaction of ethnomusicologists and cultural intelligentsia, migrate to the city and appropriate more modern forms of popular music. For example, it is a perception among certain circles of intelligentsia that Georgian rap mostly attracts village hicks who migrate to the city. ${ }^{41}$ Many of those who stay in villages, too, listen to and practice more modernized and hybrid forms of folk music, which are viewed as kitsch or a distortion of tradition. It is symptomatic that, as part of a UNESCO-funded program for safeguarding Georgian polyphony, ethnomusicologists based at the Tbilisi Conservatorium developed and implemented a program to teach villagers authentic rural singing styles and genres in 2006-07, exemplifying their teaching methods with archival recordings of the 1930s. However, I observed in one case that the villagers preferred to keep to their own established ways of performing songs, which were influenced by Soviet practices and other modernizing trends, and to preserve their repertoire of "non-authentic" songs (fieldwork in Ts'alk'a, August 2007). The preservation and transmission of heritage has thus assumed a new direction, flowing from the urban elite and scholars of the folk song tradition back to the rural "bearers" of that tradition.

This detachment of "folk music" from rural populations has occurred since the nineteenth century, when folklore began to be collected and folk song became an identity marker for the patriotic elite, entering archives, song collections, and research fields. Folk song eventually came to be viewed in two separate interpretive categories: 1) as part of the social life of the people, embedded in the social practices of the lowclass rural populations that were its supposed carriers, and 2) as actual songs or as a sound, regardless of who performed them. In many rural areas, however, folk song as part of life eventually became passé, and the songs recorded from villagers in the second half of the nineteenth century and the first half of the twentieth became a sound category only, part of archives and the repertoires of folk ensembles. Folk song as a sound category resembles the notion of heritage as a mode of cultural production, which gives the endangered or outmoded a second life in the form of performances at festivals and exhibitions. ${ }^{42}$ Thus, an organic homology between rural society and folk song became an idealized and romanticized invention of the nationalist elite-

\footnotetext{
${ }^{41}$ This perception reveals the existence of two contradictory elite discourses about rural Georgians. One sees them as ethnic Georgians preserving the purest folkloric tradition, the other as backward hicks lacking progress and modernity, an internal, exotic other. Discussion of this dichotomy is, however, beyond the scope of this article. On this question, see Nino Tsitsishvili, "From Folk Song to Jazz and Rap: Elite and Popular Musical Cultures of Tbilisi," in Urban Cultures, Urban Futures. City Culture and City Planning in Georgia, ed. Kristof Van Assche, J. Salukvadze and N. Shavishvili (Lewiston, N.Y.: Mellen Press, 2009) (Georgian edition: Tbilisi: Tbilisi State University Press).

${ }^{42}$ Barbara Kirshenblatt-Gimblett, "Theorizing Heritage," Ethnomusicology 39, no. 3 (1995): 369, and her "Intangible Heritage as Metacultural Production," Museum 56, nos. 1-2 (2004): 52-65.
} 
bourgeois and its socialist successor, the intelligentsia, and of both groups' cultural policies. ${ }^{43}$ As Charles Keil has written, "there never were any 'folk' except in the minds of the bourgeois." 44 True, as Peter Manuel observes, some cultures distinguish between folk, art, and popular music styles, and such distinctions must be taken into account when analyzing music. ${ }^{45}$ However, if we do not intend to view "culture" as a unitary category, we might as well note that such distinctions are initially made by (often elite) cultural experts rather than by the whole society or by the lower class "folk." These distinctions subsequently become hegemonic as they are spread across society through educational institutions, the media, and other discursive channels.

Since the nineteenth century, elements of Georgian folk song have entered into various other musical genres and styles and provided a basis for musical experimentations in classical Georgian art music, popular music and, more recently, in rock and experimental fusion styles. In the second half of the nineteenth century, Georgian composers educated in the style of Russian and West European classical music, aspired to provide a Georgian national classical musical styles based on the infusion of Georgian folk music into the forms of classical European music, a practice well-known in other European and non-European countries. At the beginning of the twentieth century, the first examples of Georgian classical art music were created. Starting from the 1960s, popular bands such as, for example, Orera and Rero ${ }^{46}$ began to blend Georgian folk music with modern jazz-pop-rock. More recently, ensembles such as Detsishi and particularly the critically acclaimed German-based group The $\mathrm{Shin}^{47}$ have taken this experimental fusion style to a new expressive level. The Shin's ability to blend Georgian polyphony and folk improvisational techniques with scat, folk song harmonies and elements of jazz and jazz-rock and other world musics has earned them popular acclaim throughout Europe and in Georgia. ${ }^{48}$ There have even been attempts to use traditional Georgian songs in rap, one of the most recent genres of Georgian popular music. To many ethnomusicologists in Georgia, these new fusion genres, which use folk song as sound material for experiments, are seen as a threat endangering the authenticity of the song, and represent a feared hybridity. ${ }^{49}$ However, in these hybrid musical contexts folk song is transmitted, continued, and appropriated as part of artistic experimentations and expressions, and there is therefore no evidence that folklore and folk sound is consequently endangered or vanishing. ${ }^{50}$

There is a position in the discourse of Georgian ethnomusicologists which states that "Polyphony is the Georgian man's way of life and thinking" and that "we have to resemble our elders." Wi With a view of polyphony as "under threat," Georgian thinking has maintained its orientation towards tradition and preservation, especially among scholars and state cultural policy-makers. ${ }^{52}$ It is often said that Moderni-the

\footnotetext{
${ }^{43}$ Nino Tsitsishvili, National Unity and Gender Difference in Georgian Traditional Song-Culture: Ideologies and Practices (PhD diss., Monash University [Melbourne], 2004), 53-8.

${ }^{44}$ Charles Keil, "Who Needs 'the folk'?" Journal of the Folklore Institute 15 (1978): 263-5.

${ }^{45}$ Peter L. Manuel, Popular Musics of the Non-Western World: An Introductory Survey (New York: Oxford University Press, 1988), 1.

${ }^{46}$ Some of the songs by these ensembles can be found on YouTube. Of particular interest for the reader might be "Krimanch'uli" [yodeling] by the ensemble Orera; available from http://au.youtube.com/watch?v=AzL-dKygoMk.

${ }^{47}$ Group "Detsishi" (S,Z,N. Lezhavas). Modern Georgian Ethno-Music (CD [no number], Tbilisi: Studio 33a, 2002); Zumbaland. Adila (CD SS-DC-0298, Tbilisi: Sano, 2006). The Shin Meets Georgika. Ibero-Caucasian Style World Jazz DVD Video [no number], 2004); The Shin. EgAri (CD, Jaro Medien GmbH 4278-2, 2006).

${ }^{48} \mathrm{http}: / /$ www.theshin-music.com/press.php, accessed 20 October 2008.

49 Pers. comm. during fieldwork in Tbilisi, 2008.

${ }^{50}$ In 2008, the festival Jazi da Polk'lori [Jazz and Folklore] was launched in Georgia, which signifies an elite perception of jazz as high art, and of its fusion with folklore as a desired direction for innovations in folk music.

${ }^{51}$ Malkhaz Erkvanidze interviewed by Baia Asieshvili, October 31, 2006 (in Georgian). The Folklore State Centre of Georgia. http://www.folk.ge/stumari.php?f=16\&page=0, accessed October 17, 2008); see also The Presentation of the Georgian Song and

Sacred Chant Foundation, http://www.patriarchate.ge/su/360/4text.htm, accessed April 20, 2007 (no longer operational).

${ }^{52}$ See, for example, The Presentation of the Georgian Song and Sacred Chant Foundation,

http://www.patriarchate.ge/su/360/4text.htm; "Georgia: Religion, State and Society" (Tbilisi: The Caucasus Institute for Peace,
} 
term often used to describe folk-pop-rock fusion styles - does not mix well with folk music, and that styles derived from hybridization are nothing but the manifestation of eclectic mannerism and an unnecessary interference in folklore. ${ }^{53}$ However, one could argue that these hybrid musical styles actually exemplify UNESCO's understanding of the "new" and "innovation" as being based on the continuation of traditional practices. $^{54}$ In fact, the creation of "new culture" can also be seen as a result of the "preservation of tradition," 55 which can be exemplified by many Georgian folk-fusion ensembles who mix traditional Georgian folk tunes with jazz, rock and world music sounds.

Aspects of folk music as a collectively shared social practice can actually be seen developing in the rap, rock, and popular song of Georgia's emerging youth class, i.e. in practices which are not viewed as "heritage" and "culture." Despite their Western origins, Georgian pop, rock, and rap can be seen as providing a socio-political commentary on acute issues of social reality in Georgia, including sexual liberation, drug use, poverty, political concerns, and the state's neglect of the population. Hip-hop seems to be particularly associated with and adopted by the lower-class youth who come from the outer suburbs of Tbilisi and from regional towns, and with the "street boys" (kuchis bich'ebi).

Based on a comparative historical analysis of the architecture of Tbilisi, Paul Manning has observed that "the post-socialist period has witnessed an unprecedented rural immigration into the city, as erstwhile villagers abandon the defunct rural economy for the city, and, at the same time, erstwhile city-dwellers flee the defunct national economy as guest-workers abroad. Some villages, indeed, have more or less lost their entire populations, just as some city neighborhoods are now populated primarily by recent ex-villagers. 'Real' Tbilisians, many of whom have genealogies in the city that are no more than 2-3 generations deep, find themselves faced by a horde of socially alien Georgian villagers, who bring with them behaviors once statically associated with village life." society is today witnessing a reshuffling of economic power, as working class rural populations fleeing their villages emerge in the middle-class culture. They are pejoratively called kajebi (sing. kaji, in folk tales an evil, devil-like creature with horns) and gorsalebi (sing. gorsala, an uncultured, ignorant person and a newcomer to an urban environment) or goimebi (sing. goimi, an ignorant and innocent villager, not familiar with cool stuff or the higher spiritual concerns of city intellectuals) by the intelligentsia. Kajebi have "swamped" the city, in the opinion of the older intellectual elite, and they supposedly have no Enlightenment, education, or upper-class habits. The "old intelligentsia" of the Soviet time (the term is from political philosopher Ghia Nodia), including scholars and music critics, are horrified to see the advance of this new class. The "people" are thus idealized as an ethnically pure, genetic source of folklore when they stand as an absent mass behind the sound of folk song as appropriated by elites, but when the same "people" flow to the city and make hip-hop, they become a low, instinct-driven mob which challenges the intelligentsia's imagined world of "culture" and "civilization."

Popular music can thus be seen as deeply rooted in social practice, as indeed can any kind of music. As such, popular music demonstrates that homological link between "people" and "culture" which Georgian ethnomusicologists claim is the attribute of "folk music" alone. In this respect, the concept of "intangible heritage" seems to draw far too strict a boundary between folk and popular music, to gloss over class

Democracy and Development Bulletin no. 8, August 2006) (in Georgian), available from

http://www.caucas.itdc.ge/index.php?sec id=39\&lang id=ENG, accessed 1 June 2007.

${ }^{53}$ Erkvanidze, interview.

${ }^{54}$ UNESCO. Convention on the Protection and Promotion of the Diversity of Cultural Expressions (2005), 3, 12.

${ }^{55}$ Van Ginkel, 23.

${ }^{56}$ Paul Manning, "The City of Balconies: Elite Politics and the Changing Semiotics of the Post-Socialist Cityscape," 16. available for downloading at http://www.dangerserviceagency.org/workingpapers.html, accessed 20 October 2008. Also forthcoming in Van Assche, Salukvadze and Shavishvili. 
struggles, and diminish the social significance of popular music. Under particular scrutiny and criticism fall those new popular styles which seem to have no stylistic connection with Georgian folk music, and especially rap. ${ }^{57}$ This does not mean that Georgian polyphonic song has or should have no application amongst wider populations or that it should be relegated to the past; on the contrary, many musical genres and sub-cultures have utilized folk song as material for experimentation and innovation. As Lauren Ninoshvili observes, the characteristic synthesis of traditional polyphonic music and global jazz-influenced sound enables these new ensembles to facilitate musical experimentation and intercultural dialogue (rhythmic, harmonic and textural). ${ }^{58}$ But for Georgian ethnomusicologists, neo-folk fusion signifies feared social transformation and globalization, which may facilitate the disappearance and destruction of "intangible cultural heritage," and UNESCO's 2003 Convention for the Safeguarding of the Intangible Cultural Heritage reflects these concerns when it states that globalization and social transformation, alongside the conditions they create for renewed dialogue between intra-national and international communities, also give rise to grave threats of deterioration, disappearance, and destruction of "intangible cultural heritage." Paradoxically, however, it is this kind of fusion that links the ideas of the preservation of cultural heritage, renewed dialogue between cultures and promotion of human creativity that are prominent in UNESCO pronouncements and documents. In fact, the relative accessibility of Georgian folk-fusion may generate increased interest in traditional sources of polyphony among Georgians and non-Georgians alike. ${ }^{59}$ An illustration of this was The Shin's performances of "jazzed-up" traditional songs in collaboration with young Georgian pop singers in the Georgian pop song contest "Geostar" in 2008. ${ }^{60}$

Jazz-folk fusion might well represent UNESCO's commitment to the promotion of "cultural diversity as an adaptive process and as a capacity for expression, creation and innovation" rather than as an "unchanging heritage." ${ }^{\prime 61}$ However, creativity within UNESCO ideology seems to translate into recreation, maintenance, and transmission from generation to generation ${ }^{62}$ rather than into a promotion or acceptance of new forms. Therefore, forms of popular music, other than folk-jazz fusion, that do not contain folkloric elements do not qualify as cultural expressions worthy of safeguarding by UNESCO. Interestingly, though, one might argue that popular music does not need UNESCO's protection, since its popularity does much to safeguard its survival. ${ }^{63}$ However, the influence of national politics and UNESCO's concept of intangible heritage with their focus on Georgian polyphonic folk song has far-reaching consequences.

\section{Conclusion}

Georgian ethnomusicological research today seems deeply guided by an ideology of "rescue;" much serious research is seen to be needed to protect and restore the heritage of polyphonic singing. Those fields of culture which do not need rescuing are seen as unworthy of serious research or inclusion in school and Conservatorium music and ethnomusicology curricula. Genres such as experimental fusion, popular and film music, the duduki and the zurna traditions and rock music, which are perceived as representing the threat of

\footnotetext{
${ }^{57}$ For a discussion of some aspects of the use of language, rhyming and musical rhythm in Georgian popular music in general and rap in particular, see Tsitsishvili, "From Folk Song to Jazz and Rap" (forthcoming).

${ }^{58}$ Lauren Ninoshvili (forthcoming), "Acoustic Archaisms and the Language of Georgian Folk-Fusion," in Cultural Archetypes and Political Change in the Caucasus.

${ }^{59}$ Pers. comm., Lauren Ninoshvili, March 2008.

${ }^{60}$ These songs can be found on YouTube; see The Shin and Giorgi Sukhitashvili, The Shin and Giorgi Ushikishvili and other related videos.

${ }^{61}$ UNESCO Universal Declaration on Cultural Diversity (2001), 11.

${ }^{62}$ UNESCO Convention for the Safeguarding of the Intangible Heritage, 2-3.

${ }^{63}$ In fact, most popular and especially, rock music artists to whom I spoke in the summer of 2007 and 2008 expressed deep concern about the fact that there was no music industry developing in Georgia, and artists did not have many venues available for performing. But folk song ensembles have similar concerns about folk music.
} 
globalization or as unrelated to "heritage," are largely ignored. Yet these same genres give musicians the possibility of exploring alternative identities and of enabling liberation, recreation, and transformation of the folk tradition. Therefore, the selection of polyphonic song as the sole example of "intangible heritage" does not reflect the complexity and diversity of the communal cultural expressions to which UNESCO aspires. The more problematic social, cultural, and political processes that underlie Georgian music and culture are also avoided in Georgian ethnomusicology, perhaps because the investigation of such processes may undermine the political power of tradition and collective cultural identity. It seems that Georgian scholarship has yet to reach the point of combining the philosophies of unique Georgian identity and cultural dialogue at a more synthetic level, resolving its ambivalence towards new influences and exploring new possibilities for musicological research.

One might notice a link between the preservation of cultural heritage and the religious revival in Georgia. The fact that the rescue of Georgian polyphony is entangled with the revival of Orthodoxy and of polyphonic Christian chant following the end of socialism also indicates that religion and the Church play a significant role in the discourses on preservation and globalization. ${ }^{64}$ As the influential Patriarch of the Georgian Orthodox Church, Ilia II, said, "The process of globalization naturally entails assimilation and often a total obliteration of those cultures and peoples who have not developed a necessary immunity [...]. Language, fatherland and faith ${ }^{65}$ - we have to take good care of these three treasures, in order to maintain the nation's unity and uniqueness.",66

Therefore, we might also ask whose cultural identity UNESCO proclamations are safeguarding: that of the elite culture advocates and practitioners, the religious orthodoxy, or the rural populations? In answering this question, we might admit that in many cases UNESCO experts are keener to preserve the cultural uniqueness of different ethnicities than are the local rural populations themselves. The reason is that UNESCO experts and music intellectuals are more aware and afraid of the "cultural dangers" of globalization and of the gloomy picture of a homogenized world than are Georgian villagers. Some experts on Georgian culture have expressed the fear that roads, railways, and modern lifestyles might forever change the ancient, rustic life of the mountainous areas of Georgia. These fears resemble, on a narrower local scale, the Western elites' "colonial quest," "bent on preserving other people's musics before they disappear, documenting 'survivals' of 'traditional' practices, and enjoying the pleasures of exoticism into the bargain." ${ }^{, 67}$ Clearly, the world would be impoverished if unique musical styles were to disappear, and UNESCO's work is necessary if we want to avoid such impoverishment. Yet we must be cautious in defending the culture-specific rather than universalist approach, since "cultural heritages" do not vanish, but continue, albeit with less specific geographic attachment, in the more general category and social practice of music in all its genres and stylistic varieties.

\footnotetext{
${ }^{64}$ Issue no. 325 , available from $\mathrm{http}: / /$ www.georgiatoday.ge/article details.php?id=1760, accessed 20 May 2007. This issue is no longer available on the website. "The presentation of the Georgian song and sacred chant foundation," http://www.patriarchate.ge/su/360/4text.htm, 20 April 2007 (no longer operational, as noted above).

65 "Language, fatherland, faith" [ena, mamuli, sarts'munoeba] is an iconic triad formulated by the nineteenth century nationalist writer-politician Ilia Ch'avch'avadze as a symbol of the nation. In 1989, Ilia Ch'avch'avadze was canonized as a Christian saint, Ilia the True [Ilia Martali], after the post-communist reinstatement of the Church.

${ }^{66}$ Georgia: Religion, State and Society, press review (Tbilisi: The Caucasus Institute for Peace, Democracy and Development, Bulletin no. 4, April 2006), 4 (in Georgian).

${ }^{67}$ Middleton, 146.
} 


\title{
Acknowledgements
}

This article is an extended version of the paper presented at the 39th World Conference of the International Council for Traditional Music, Vienna, Austria, July 4-11, 2007. I wish to thank Kay Dreyfus and Joel Crotty, who invited this contribution for Music and Politics, and Kay Dreyfus for her critical readings as a guest editor of the journal and as a colleague. Special thanks go to Lauren Ninoshvili, who gave comments on the earlier version of this paper, to two anonymous reviewers and Wim van Zanten, for their thoughtful feedback which will be most useful for the future development of this research.

\begin{abstract}
This article examines the effects of UNESCO's 2001 proclamation of Georgian polyphonic song as a "masterpiece of oral and intangible heritage." Related ideas about tradition and the safeguarding of traditional cultures are examined, as is the impact of globalization, its perceived threats and the opportunities it creates for cultural diversity, cultural exchange and dialogue. By analyzing paradoxes and contradictions arising from UNESCO's definitions of and action plans towards "intangible cultural heritage," the article demonstrates that the features selected by UNESCO as characteristic of "intangible heritage" - oral traditions and expressions, performing arts, social practices, and knowledge and practices concerning nature and the universe - are also found in modern Georgian popular music genres such as pop, rock, and rap, though these genres are not viewed as cultural heritage. The article thus argues that, while the longterm nationalist cultural policies endorsing the primacy of Georgian traditional polyphony have found a new ideological endorsement within UNESCO's discourse of culture, the reality of the country's cultural life is not accommodated.
\end{abstract}

